\title{
Go-jek Swipe Token VS Shopee Games: The Effect of Difficulty on Gamified Loyalty Program Towards Behavioral Intention and User Attitude
}

\author{
$1^{\text {st }}$ Muhammad Gilang Aditya ${ }^{1}, 2^{\text {nd }}$ Daniel Tumpal Hamonangan Aruan ${ }^{2}$ \\ $\left\{\right.$ m.gilang.aditya@gmail.com ${ }^{1}$,dtumpal@ui.ac.id $\left.{ }^{2}\right\}$
}

\begin{abstract}
University of Indonesia, Jl. Margonda Raya, Pondok Cina, Kecamatan Beji, Kota Depok, Jawa Barat $16424^{1}$, University of Indonesia, Jl. Margonda Raya, Pondok Cina, Kecamatan Beji, Kota Depok, Jawa Barat $16424^{2}$
\end{abstract}

\begin{abstract}
Gamification is a method where game elements are used in a non-video game context. The aim of this research is to find out the effect that gamification had towards behavioral intention and whether different on difficulties in gamification could change those effect or not. The methodology used is descriptive research by using two-hundreds samples that are divided into two different groups of Go-Jek and Shopee based on gamification design and difficulty. The result shows that difference in design and difficulty have significant effect on the result of gamification, in simple design gamification have a significant effect towards behavioral intention. On the contrary, gamification with more complicated design gamification has significant effect on perceived usefulness. Lastly, though gamification has a positive significant effect on user attitude towards loyalty program, it does not have a significant effect on behavioral intention. Based on this result, the difference on difficulty does affect gamification result.
\end{abstract}

Keywords: Consumer Attitude, Consumer Behaviour, Gamification, Loyalty Program, M-commerce

\section{Introduction}

Gamification is a method, where a single or many elements that often found in a video game are used for non-video game context [1]. The usage of gamification itself varies greatly, from small thing such as a voting or point system that can be found in e-commerce sites such as Amazon to something much more complex. Gamification is often seen as an interesting method to promote a product or brand because of its ability to create an engagement between the end user and the product [2]. Nowadays, a lot of m-commerce application in Indonesia such as Go-Jek, Shopee, and Tokopedia decides to use gamification for their loyalty program. This is interesting since usually, a game are devoid of any utilitarian feature and created to be as attractive as possible to create an addictive experience for their player [3]. Yet, by combining it with loyalty program, it might be able to change consumer perspective towards the loyalty program itself, hence, affecting their attitude on how they see the program. However, it is still a mystery whether that attitude towards the loyalty program will have any effect on user intention to keep using the m-commerce application. 
On previous research by Jurado (2019), Jurado found that gamification have different effect on different generation of samples. The result of Jurado research shown that gamification have better results on millennial samples when compared to generation $\mathrm{X}$ samples. However, we think that there are other variables that might be able to affect the results such as the difficulty of the gamification feature itself. Difficulty is one of the main aspects in a game mechanic. When we play a video game, we often get to choose what kind of difficulty we want to play it. Other element that are also important other than mechanic for a game is story, aesthetic, and technology used to build the game [4], [5]. Another research by Hwang and Choi (2020) found that when gamification combined with a loyalty program it have significant effect towards user intention to download application needed to play the loyalty program and intention to participate on said loyalty program. However, one of the limitations on Hwang and Choi research is that their model is unable to determine gamification effect further towards user intention on keep using the application. Our research aimed to answer both gaps from Jurado, and Hwang and Choi research. We want to know whether difficulty in gamification will yield different results on user intention, while also to find-out whether user attitude towards gamified loyalty program have significant effect on the same intention.

\section{Literature Review}

\subsection{Gamification Elements}

Gamification is an effort to implement video game element to non-video game context. The use of such game element is to motivate people to do something that creates more value towards the product, such as more consumption or higher loyalty [5], [6]. Video game elements that are usually used and applied on a non-video game context are those that have the form of point, badges, and leader board [7], [8]. In gamification, point and badges are there as some sort of reward given to user or participant as an appreciation for his/her efforts on participating in the gamification. Leader board, however, works differently from those of points and badges. If points and badges work as a reward, leader board work as way to motivate participant to compete with other participants [7], [9].

\subsection{Attitude Towards Customer Loyalty Program}

Customer loyalty program is a marketing initiative aimed to increase customer loyalty toward a product through offering an incentive to a group of profitable customers [6], [10]. Customer loyalty program is also known able to increase consumption behaviour toward a product over time without the needs to change price or alter the main offering of those products [6], [11]. The main reasons a firm wanting to apply customer loyalty program is to increase purchase intensity and to shape consumer habitual consumption [6], [12].

Customer loyalty program existed because some customer would love more involved relationship with the product they purchased. This customer tended to be more loyal than other 
customers that did not have the desire to be more involved on that product, hence this group of customers considered to be a profitable group [6], [10]. Through using customer loyalty program, it is possible to further reinforce their loyalty, making them behave like a long-time customer [10]. Attitude is how individual perceives and evaluates a focal entity or a behaviour positively or negatively [6]. Attitude towards loyalty program is important as it determines whether someone willing to participate on the customer loyalty program or not [6], [13].

\subsection{Technology Acceptance Model}

Technology acceptance model (TAM) is a model that is adapted from theory of reasoned action (TRA) which were first created by Fishbein and Ajzen (1980). TAM is often used to determine the reason behind why someone decides to accept or deny a new emerging technology [14], [15]. To be able to measure whether someone is going to deny or accept a technology, TAM needs to predict that person intention first by measuring their experience from the interaction with said technology. TAM predicts the behavioral intention of people toward actual system use of a technology by using perceived usefulness, perceived ease of use variables formed by that person attitude toward using said technology.

Perceived usefulness in TAM model is user perspective on how helpful a technology is, how much it can assist user on their daily activities and/or when doing their jobs. While perceived ease of use is how user perceive the difficulty of learning on using a technology. People always expect that there will be no difficulty mentally or physically to learn on using a new technology. A good perceived usefulness and perceived ease of use can result on a good behavioral intention [7], [16].

\section{Methodology and Data Analysis}

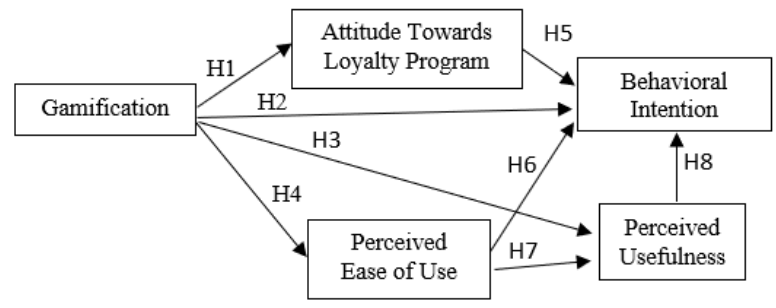

Fig. 1. Research Model

Measurement that was used for gamification, perceived usefulness, perceived ease of use and behavioral intention in this research is adapted from prior work by Jurado, Gonzalez, Jimenez, and Rodrigues (2018). The attitude towards loyalty program variables is also 
important to be measured in this research as we are trying to find-out does gamification have any effect on how people view a loyalty program. For measurement used to measure attitude towards loyalty program, we adapt it from prior work by Hwang and Choi (2020).This model are also created to answer one of the question that Hwang and Choi have on their research. One of the limitations in Hwang and Choi research is that their model cannot be used to determine user intention to keep using the application. Behavioral intention in Jurado model is used to seek whether user willing to keep using the application and to recommend it to their friends after having the experience of gamification. Hence, by modify Jurado model with Hwang and Choi model we expect to be able to find whether gamification and attitude towards loyalty will have any effect on user intention to keep using the application or not.

The scale used for gamification, perceived ease of use, perceived usefulness and behavioral intention is 5 points scale Likert scale that range from very disagree to very agree. Meanwhile the scale that is used on attitude toward customer loyalty program is bipolar 5 points scale with four different measurement that are consisted of unfavorable to favorable, unpleasant to pleasant, bad to good, and negative to positive. Survey was then distributed through 211 total respondents with 103 respondents given questionnaire regarding gamification from Go-jek and 108 respondents given questionnaire regarding gamification from Shopee. Survey distributed by using self-administered online survey method. Main survey data then processed by using SmartPLS and bootstrapped. Reason for using SmartPLS is because SmartPLS is a good tool for a predictive research model, where on this research writer is trying to predict user intention.

\section{Research Result and Discussion}

Table 1. Research results of one-tail test from Go-jek and Shopee sample data.

\begin{tabular}{llll}
\hline Variable & Indicator & $\begin{array}{l}\text { R Square (Go- } \\
\text { jek/Shopee) }\end{array}$ & $\begin{array}{l}\text { Outer Loading (Go- } \\
\text { jek/Shopee) }\end{array}$ \\
\hline GM & GM1 & - & $0.624 / 0.686$ \\
& GM2 & & $0.703 / 0.762$ \\
& GM3 & & $0.776 / 0.651$ \\
LP & GM4 & $0.192 / 0.175$ & $0.638 / 0.851$ \\
& LP1 & & $0.879 / 0.849$ \\
& LP2 & & $0.913 / 0.922$ \\
PU & LP3 & & $0.911 / 0.867$ \\
& LP4 & $0.633 / 0.468$ & $0.917 / 0.862$ \\
& PU1 & & $0.783 / 0.895$ \\
PEU & PU2 & & $0.825 / 0.847$ \\
& PU3 & & $0.851 / 0.758$ \\
BI & PU4 & $0.129 / 0.165$ & $0.706 / 0.723$ \\
& PEU1 & & $0.910 / 0.883$ \\
& PEU2 & & $0.771 / 0.732$ \\
& PEU3 & & $0.912 / 0.878$ \\
& BI1 & $0.531 / 0.505$ & $0.867 / 0.819$ \\
& BI2 & & $0.850 / 0.770$ \\
& BI3 & & $0.860 / 0.704$ \\
& BI4 & & $0.765 / 0.751$ \\
& BI5 & & $0.739 / 0.786$ \\
\hline
\end{tabular}


Table 2. Hypotheses results on both Go-jek and Shopee sample data.

\begin{tabular}{llll}
\hline Hypotheses & P-Values (Go-jek/Shopee) & $\begin{array}{l}\text { T Statistics (Go- } \\
\text { jek/Shopee) }\end{array}$ & $\begin{array}{l}\text { Results (Go- } \\
\text { jek/Shopee) }\end{array}$ \\
\hline H1 (GM -> LP) & $0.000 / 0.000$ & $5.901 / 4.887$ & Accepted / Accepted \\
H2 (GM -> BI) & $0.031 / 0.218$ & $1.854 / 0.763$ & Accepted / Rejected \\
H3 (GM -> PU) & $0.196 / 0.022$ & $0.874 / 2.013$ & Rejected / Accepted \\
H4 (GM -> PEU) & $0.000 / 0.001$ & $3.676 / 3.137$ & Accepted / Accepted \\
H5 (LP -> BI) & $0.497 / 0.294$ & $0.006 / 0.538$ & Rejected / Rejected \\
H6 (PEU - B BI) & $0.002 / 0.000$ & $2.799 / 3.945$ & Accepted / Accepted \\
H7 (PEU -> PU) & $0.000 / 0.011$ & $12.601 / 2.273$ & Accepted / Accepted \\
H8 (PU -> BI) & $0.014 / 0.025$ & $2.122 / 1.997$ & Accepted / Accepted \\
\hline
\end{tabular}

The result of $\mathrm{H} 1$ shows that gamification have significant effect towards attitude towards loyalty program. O'Brien and Jones (1995) once said that for a loyalty program to be able to be accepted by customers, it has to be possible for the said customer to get the reward offered in the program. By using gamification, it creates a perspective that the reward on the loyalty program itself are easily achievable by playing games. On the other hand, games often seen as a way of recreation, which also affect customers perspective when they are going through the process of said loyalty program. However, H5 are rejected on both samples. Based on personal question that writer had ask from the respondent, writer found that for respondent goal and rewards is two important factors in a gamification. It is possible that positive attitude was generated because of the rewards offered, which motivated user to participate only for the reward and for the game feature. User might only use the applications to get chance on playing the game or to use said rewards on the m-commerce platform. If the loyalty program and gamification is cancelled or stopped there might be a possibility where the user might stop using the m-commerce.

$\mathrm{H} 2$ and $\mathrm{H} 3$ results are interesting because both samples show different results. $\mathrm{H} 2$ results might be affected by the design of the gamification itself. On a simple design gamification such as Go-jek that can only be played after a transaction with no complicated rule on playing the game, made user treat the game feature and the rewards as an incentive for them to kept using Go-jek which in turn create a good intention. The fact that Go-jek had also became a necessity also help on creating said intention. On the other hand, on a more complicated design and higher difficulty one such as Shopee Games, user treat the game just like a standalone game due to the immersion created by the games. People enjoy participating on Shopee Games because it is a game that have rewards which can be used on Shopee, not because they feel rewarded for using Shopee. However at the same time, due to this kind of design and immersion created by the Shopee Games, user also perceive Shopee for being more useful than it's intended purpose, due to the game feature can be used as a source of recreation and filling time. This proven by $\mathrm{H} 3$, whereas on a simpler design and lower difficulty, gamification cannot provide said recreation. Using gamification also help m-commerce on improving their perceived ease of use, this proven by $\mathrm{H} 4$ results. By having game features where you need to use the application to gain chance on playing the game much like Go-jek and Shopee gamification and where the rewards can only be used on said m-commerce platform, made user more willing to learn on how to use the application. 
H6, H7, and H8 on both samples are accepted. This shows that perceived ease of use and perceived usefulness have an important role on shaping user intention to keep using the application. Even though gamification might not be able to affect behavioural intention significantly directly much like Shopee sample $\mathrm{H} 2$ result, but it can be used to create a perspective where using Shopee is much easier compared to other application and that Shopee is more useful with their game feature compared to others. Which in turn, improving user intention on keep using Shopee instead of other application. Perceived ease of use also proven to be able to help gamification on creating more perceived usefulness on a m-commerce application, this result is corresponding with the technology acceptance model itself. When a $\mathrm{m}$-commerce application is seen as easy to use, user will perceive that the application is useful since it can help them to be more efficient on doing daily activities compared to when they did not use the application.

\section{Summary}

Overall gamification is a good way to shape positive attitude towards a loyalty program on user when paired together. However, for a gamification with complex design and higher difficulty, to be able to create intention it need a good degree of perceived ease of use and perceived usefulness on the application itself. In simple design gamification, perceived ease of use and perceived usefulness are not that necessary as it can shape intention by itself. Gamification with simple design and low difficulty will not be able to improve the perceived usefulness of an application, while more complicated one is able to do so. Although, this result might be because of Go-jek that are already perceived as useful even without the game feature, since today, Go-jek is often considered as daily necessities application by its user. It is also to be noted that attitude towards loyalty program have no significant effect on behavioral intention, which mean company need to look deeper than user reaction to determine whether gamification on a loyalty program succeeded on shaping intention to keep using the application or not.

\section{Implications / Limitations and Suggestions for Further Research}

The implication of this research is that when company decided to design a gamification to promote their loyalty program, it is important for that company to look at the design of their own m-commerce application. For m-commerce that already became a daily necessities such as Go-jek, company might have no need to create a gamification with high level of immersion, as user already perceive the application useful. While, for m-commerce that are rarely used such as Shopee, gamification with high immersion might be needed to keep user to access the application as often as possible. The limitation of this research is that this research was done by using samples from Indonesia; samples from another country may yield different results than this research. The gamification used in this research are also one that are used for a loyalty program with point system. Future research can try to research by using example of gamification that use leaderboard and badge system or gamification that are created not for the purpose of promoting a loyalty program. Variables that might be able to change the results of attitude towards loyalty program towards intention to keep using the application can also become future topic for research. 


\section{Reference}

[1] S. Deterding, M. Sicart, L. Nacke, K. O’Hara, and D. Dixon, “Gamification. using game-design elements in non-gaming contexts," in CHI'11 extended abstracts on human factors in computing systems, 2011, pp. 2425-2428.

[2] T. Leclercq, I. Poncin, and W. Hammedi, "The engagement process during value cocreation: gamification in new product-development platforms," Int. J. Electron. Commer., vol. 21, no. 4, pp. 454-488, 2017.

[3] S. M. Grüsser, R. Thalemann, and M. D. Griffiths, "Excessive computer game playing: evidence for addiction and aggression?," Cyberpsychology Behav., vol. 10, no. 2, pp. 290-292, 2006.

[4] J. Schell, The Art of Game Design: A book of lenses. CRC press, 2008.

[5] C. F. Hofacker, K. de Ruyter, N. H. Lurie, P. Manchanda, and J. Donaldson, "Gamification and Mobile Marketing Effectiveness," J. Interact. Mark., vol. 34, no. 2016, pp. 25-36, 2016, doi: 10.1016/j.intmar.2016.03.001.

[6] J. Hwang and L. Choi, "Having fun while receiving rewards?: Exploration of gamification in loyalty programs for consumer loyalty," J. Bus. Res., vol. 106, no. November 2017, pp. 365-376, 2020, doi: 10.1016/j.jbusres.2019.01.031.

[7] A. García-Jurado, P. Castro-González, M. Torres-Jiménez, and A. L. Leal-Rodríguez, "Evaluating the role of gamification and flow in e-consumers: millennials versus generation X," Kybernetes, vol. 48, no. 6, pp. 1278-1300, 2019, doi: 10.1108/K-072018-0350.

[8] J. Hamari, J. Koivisto, and H. Sarsa, "Does gamification work?--a literature review of empirical studies on gamification," in 2014 47th Hawaii international conference on system sciences, 2014, pp. 3025-3034.

[9] I. Bunchball, "Gamification 101: An introduction to the use of game dynamics to influence behavior," White Pap., vol. 9, 2010.

[10] Y. Yi and H. Jeon, "Effects of loyalty programs on value perception, program loyalty, and brand loyalty," J. Acad. Mark. Sci., vol. 31, no. 3, pp. 229-240, 2003, doi: 10.1177/0092070303031003002.

[11] C. M. Henderson, J. T. Beck, and R. W. Palmatier, "Review of the theoretical underpinnings of loyalty programs," J. Consum. Psychol., vol. 21, no. 3, pp. 256-276, 2011.

[12] W. Wood and D. T. Neal, "The habitual consumer," J. Consum. Psychol., vol. 19, no. 4, pp. 579-592, 2009.

[13] M. D. Uncles, G. R. Dowling, and K. Hammond, "Customer loyalty and customer loyalty programs," J. Consum. Mark., 2003.

[14] R. Fayad and D. Paper, "The technology acceptance model e-commerce extension: a conceptual framework," Procedia Econ. Financ., vol. 26, pp. 1000-1006, 2015.

[15] M. M. Luo and S. Chea, "The effect of social rewards and perceived effectiveness of e-commerce institutional mechanisms on intention to group buying," in Advances in Human Factors, Business Management, Training and Education, Springer, 2017, pp. 833-840.

[16] H. Van der Heijden, "Factors influencing the usage of websites: the case of a generic portal in The Netherlands," Inf. Manag., vol. 40, no. 6, pp. 541-549, 2003. 